IRA-International Journal of Management \& Social Sciences

ISSN 2455-2267; Vol.07, Issue 01 (2017)

Pg. no. 96-102

Institute of Research Advances

http://research-advances.org/index.php/RAJMSS

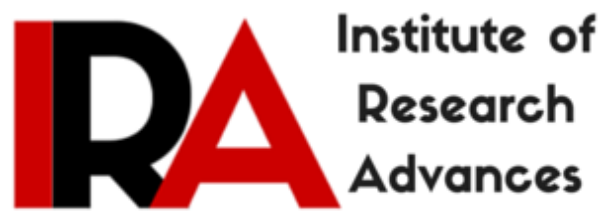

\title{
Psycho-Social Effects of Teenage Pregnancy in Masvingo Province, Zimbabwe
}

Viola Ingwani ${ }^{1}$, Shamiso Iline Chingombe ${ }^{2}$, Loveness Chindanya ${ }^{3}$, Sarah Moyo ${ }^{4}$

${ }_{1,2,3,4}$ Lecturer at Great Zimbabwe University, School of Education, Department of Educational Foundations, Zimbabwe .

Type of Review: Peer Reviewed.

DOI: http://dx.doi.org/10.21013/jmss.v7.n1.p11

\section{How to cite this paper:}

Ingwani, V., Chingombe, S., Chindanya, L., \& Moyo, S. (2017). Psycho-Social Effects of Teenage Pregnancy in Masvingo Province, Zimbabwe. IRA-International Journal of Management \& Social Sciences (ISSN 2455-2267), 7(1), 96-102. doi:http://dx.doi.org/10.21013/jmss.v7.n1.p11

(C) Institute of Research Advances

(cc) EY-NC

This work is licensed under a Creative Commons Attribution-Non Commercial 4.0

International License subject to proper citation to the publication source of the work.

Disclaimer: The scholarly papers as reviewed and published by the Institute of Research Advances (IRA) are the views and opinions of their respective authors and are not the views or opinions of the IRA. The IRA disclaims of any harm or loss caused due to the published content to any party. 


\section{ABSTRACT}

This qualitative research design focused on the psychological effects of teenage pregnancy in Masvingo Zimbabwe. In depth interviews were employed for data collection. The sample compromised five school girls with friends who dropped out of school due to teenage pregnancy, five girl child drop outs and three elders knowledgeable in Shona culture. The analysis was concerned with the attitudes of Shona society on teenage pregnancy and dropping out of school; in particular the girls' family, the girls' prospective inlaws, her school peers and the church. Findings revealed the trauma that the pregnant girl-child faces. It was noted that she suffers rejection, isolation, shame and low self esteem. Furthermore due to economic hardships the boys responsible for the pregnancy are not economically ready to start a family. Prospective in-laws discourage marriage because they feel that their boy children are not ready for marriage and are being taken advantage of. Recommendations were made that the family and the society should take a more supportive role when faced with pregnant teenagers.

KEY WORDS: psycho social, teenage pregnancy

\section{BACKGROUND}

The study navigates the psychosocial effects of teenage pregnancy in Masvingo province, Zimbabwe. Ogori, Ajeya and Yunusa (2013:1) carried out a study in Niger State on the causes and effects of teenage pregnancy. The findings revealed that the teenagers are engaged in sexual intercourse due to lack of sex education and non- use of contraceptives during intercourse. Traffers (2003) reports that the highest rate of teenage pregnancy in the world is in sub-Saharan Africa where women tend to marry at an early age. Amedeker ( 2011) asserts that a large percentage of female high school dropouts in Ghana are the result of factors such as early marriage and early sexual activity.

Tsoaledi ( 2015: 273) carried out a study in South Africa and noted that most pregnancies were between the girls aged 16-19. The pregnancies were propelled by lack of parental guidance and role models in the village . Chigona and Rajendra (2007:1) noted that teenage pregnancy has militated against the educational success of girls in South Africa. This revelation shows that the girl child is affected since, once education is disturbed, the avenues to better life are blocked. The researchers noted that a few researches focusing on teenage pregnancy have been done in Chivi District in Zimbabwe. This has prompted them to explore the psycho social effects of teenage pregnancy in this particular district.

\section{LITERATURE REVIEW}

According to Chapman et al (2011) a large percentage of female dropouts indicate that balancing work, school and child-rearing responsibilities is a daunting task; therefore some girls opt out of school. Further, some studies indicate that many girls in Southern Africa give birth during their teenage years when they are neither economically nor emotionally ready to deal with parental responsibilities (Odimengwu and Mkwananzi, 2016).

Brown (2003) supports the above view when he cites sociological evidence on abandonment of babies by teens. The evidence makes it clear that teens are not ready to take social and economic responsibility for the birth of the baby. Medically, some pregnant teenagers face poor maternal and parental health (Jacobson ,2001). This is exacerbated by the fact that pregnant teens are less likely to receive prenatal care, only seeking it in the third trimester.

\section{THEORETICAL FRAMEWORK}

It is imperative to outline the theoretical framework that we engaged in this research, vis a vis the African women's liberation perspective. It is similar to Masenya's African woman's liberation perspective and focuses on black women's freedom and unshackling (Dube, 2001). 
The framework alludes to a plethora of forms of oppression experienced by females in African patriarchal settings. Patriarchy is the prime obstacle to women's advancement and development (Sultana 2011:1) . Patriarchy is also seen as a political- social system that insists that ales are inherently dominating, superior to everything and everyone deemed weak especially females and endowed with the right to dominate and rule over the weak and to maintain that dominance through various forms of psychological terrorism and violence ( Louisville Anarchist Federation http:// LAFF-experiment.org). According to the African women's liberation perspective, patriarchy lends women docile and submissive (Dube, 2001). The Shona culture in this case leaves the girl child vulnerable and lacking empowerment on sexual matters. Worse, when she falls pregnant, social support is missing from parents, neighbors, relatives, the school and church due to ingrained cultural attitudes and perceptions.

In Shona culture, gender relations are as a result of socialization. If gender relations are a product of socialization, there is a hope that human communities can shape them, (Dube, 2003). Oppressive behavior can be unlearnt by both women and men. Shona society bears certain expectations on a growing female in a patriarchal society. This means that failure to meet societal expectations may lead to negative psycho social effects. One participant in this study pointed out that women in church should treat pregnant teenagers with the kindness expected of women in this fold. Male theologians such as Chitando (2007) have called on the church to be sympathetic to pregnant girl's .In other words the church is summoned to have "friendly feet". According to this notion, the church should avoid being judgmental towards teenage pregnancy and accept pregnant teenage girls into its fold. Even the Bible teaches, "Do not judge, forgive those who do you harm..." (Matthew 7: 1-12, New King James Version). The clergy should be welcoming to such people, for they need God more. The church should provide a safety net for the teenage girl. Most girls we interviewed complained about the attitude of church going women," vana amai veruwadzano".

\section{RESEARCH METHODOLOGY}

The researchers utilized the qualitative research design which is on a social constructivism perspective with a small sample size. Pseudonyms were used for all the participants .Due to difficulty in locating the drop-outs snowball sampling was utilized. The researchers interviewed the participants and collected completed responses using an objective method.

\section{THE SAMPLE}

Muchengetwa (2005) defines a sample as a subset of the population under investigation. The sample comprised of the following participants; five school girls with friends who dropped out due to pregnancy ,five girl child drop outs and three elders knowledgeable in Shona culture.

\section{DISCUSSION OF THE FINDINGS}

\section{REACTIONS FROM FAMILY}

In Shona (Karanga) culture, when a mishap such as teenage pregnancy occurs, the official place to go is the paternal aunt, a father's sister. At times, family politics makes life difficult for the girl who has fallen pregnant. The girl's mother might not be in good books with the aunt. Therefore, when the time comes for the aunt to assist, the support is not forthcoming. However, it should be noted that this is a very rare occurrence. The paternal aunts offer refuge to their nieces when there is trouble in paradise. Most men listen to their sisters' views concerning the pregnant girl.

Yet another dimension hails from aunts who are unsympathetic to the girls and verbally abuse them before finding a solution. "Pawaivhura gumbo uchirara naJohn waifungei?"( Rudo interviewed 2013) . Translated this is:" When you opened your legs and had sex with John what did you think you were doing?". Such verbal abuse can be hurtful, scathing and wounding to a girl who needs family support. 
Findings have shown that teenage pregnancy invites ugly scenarios in the Shona setting. One respondent indicated that her boy friend was also at the same school acknowledged the pregnancy but felt that he was not yet economically independent. This situation puts pressure on the pregnant girl. While the boy may be willing to take up responsibility, his parents may feel that their little boy's education is at stake and that the girl took advantage of their son. One of the participants was quoted as saying, "My friend Loice (not real name), has left school because she got pregnant in April. Her boyfriend Sam (not real name) accepted this responsibility. Unfortunately, his rich parents chased Loice away, citing the fact that Loice was taking advantage of Sam's affluent background". Societal and family support is necessary in this instance to avert a definite stressful crisis looming in the horizon. Uglier scenes have emerged as girls in Loice's dire situation have attempted to get back to their parental home only to meet a volatile situation.

Some girls are involved in transactional sex in search for fall basic needs. According to Maslow's hierarchy of needs cited in Davison and Neale (1990), the girl lacks basic physiology needs such as shelter, food, love and belongingness . As a result, they are impregnated by elderly men in exchange of those commodities.

Other glaring examples of abuse of teenage pregnant girls are when the girl is grudgingly accepted into the boy's home. She is overworked and given very little food. Rachel (17) of School A in Masvingo cites these in-laws as cruel abusers. On closer analysis, the in-laws will harshly treat their daughter- in- law with the hope that she will go away and leave their dear boy alone. The cruel acts are meant to protect their boy's interests and the in-laws selfish ends.

On the flip side of the coin, the boy's parents may welcome the girl into their fold. Resistance may come from the girl's parents. Differing backgrounds may lead to this. Zvavanoda (19) of school B in Masvingo states that often, pregnant teenage girls, from well up backgrounds may be deterred from marriage by their own parents who look down upon their future son-in-law's family. Seemingly the economic status of the parents has a bearing on how the pregnant teen is impacted.

In some cases, the girl's family takes care of her until she delivers. However, some fathers are very patriarchal and will treat their daughters harshly .Chioniso one of the girls in the study stipulated that when Amina got pregnant and she took refuge at her grandparents, house for fear of her father's fiery temper. After two weeks, Amina's father instructed that she come home. The mother was instructed to tell her that, her father had disowned her and she was to keep to the bedroom and ensure that she was invisible when he was insight. No parental care would be afforded her, for the father had no money to waste on a prostitute. The mother, also a professional educator, had to steal family money to buy preparatory baby clothes. All children were told to keep away from Amina. It was like she had an infectious disease. Her name was not to be called in that home. Evidently the girl child faces rejection from both her parents and prospective in-laws.

One of the elders in this study said that it is a prerequisite of the African Shona society that a child must grow, be married and have a family. This is one of the reasons why pregnant teenagers are rejected. Therefore teenage pregnancy has no place in the Shona culture. A crucial factor in the scenario of a Shona child being pregnant at school is the psychological outlook of society towards this horrendous calamity. This participant further presents that teenage pregnancy in the Shona parent's eye as an unacceptable and scornful experience in society. Resultantly, the girl lacks a firm base and has no shoulder to cry on during this stressful period of her life. The parents are busy viewing this event from society's critical eyes and fail to take into cognizance the psycho social effects on the girl child. The girl faces rejection from society, family, peers and even the person responsible for the pregnancy. 


\section{SOCIETAL INSIGHTS ON THE PREGNANT GIRL}

The researchers' interviewed pregnant teenage girls ,their friends and elder members of Shona society who revealed interesting insights .Shona society has labels passed on these girls, for example "Akamitiswa or akanhumburiswa (a degrading way of stating that the girl was impregnated), ane mimba isina baba (literally means a pregnancy without a father suggesting a weak character), akahura (meaning she is a prostitute). These remarks are raw comments passed on the expecting girl with little or no regard to her feelings . They leave the girl child feeing inferior and with a low self esteem. Society becomes very judgmental towards the impregnated girl, at times without justified grounds.

\section{Through the psychological lens of the impregnated girl}

The pregnant teenage girl suffers trauma due to lack of support from parents, peers; siblings, relatives the church and society at large ." Nothing had prepared me for the scourge of teenage pregnancy. I had no family support at all. In fact, I was lonely in a home where there were more than ten members. I felt as if I was naked, everywhere I went people would stare at me", says Varaidzo of School C in Masvingo.

In particular, she demonstrates how unsupportive her family was. It felt like she was on an island alone.

\section{SIBLINGS}

Yet another dimension to consider is the pregnant girl sibling's feelings. In certain instances, parents forgive their child but some siblings hold eternal grudges when a sister falls pregnant. Different views emerged from the siblings; the sisters were supportive whilst the brothers took a condemning stance.

\section{THE SCHOOL COUNSELLOR}

At school B and D, friends of girls who got pregnant while at school commented that school counsellors do a good job counselling learners. The only challenge was that some counsellors fail to keep counselling sessions confidential thereby further prejudicing the girl child.

\section{PEERS}

Teenagers need to have friendships and to belong, according to Maslow's hierarchy of needs, (Slavin, 2000). Unfortunately when a girl gets pregnant while at school, she suddenly loses all friends. If it is at a boarding school, she has to leave school so that even those friends who sympathise with her, are geographically removed from her. Rose 18 of School C enlightens the researchers on this issue. Apart from different geographical locations,, the connection is lost as soon as one gets pregnant.

Rose further said that "we have different issues to pursue. She thinks of the unborn baby and husband while I concentrate on education. I do not see common ground here". Furthermore, most teenagers do not want to be associated with someone who left school, it is degrading according to views we collected at School B in Masvingo .This leaves the teenage girl virtually alone.

Feelings of guilt, despair and loneliness overwhelm the girl who gets pregnant while at school. Getting pregnant before finishing school usually means the end of school and hence hope wanes and fades for a bright future. Stress usually sets in and is said to be responsible for a number of ailments such as hypertension and heart disease (Slavin, 2000)

\section{RECOMMENDATIONS AND CONCLUSIONS}

The family, the church and society should cease envisaging teenage pregnancy in the narrow selfish way they are doing. It is strongly recommended that Shona society offers more support to teenage girls and boys in terms of sexual matters. Societal attitudes of the parents, siblings, school, school counselors, 
relatives, neighbors, the church needs to change so pregnant teenage high school drop outs' self esteem can be boosted.

The Ministry of Gender is urged to provide support in terms of literature, workshops and safe houses to counter this challenge. Through teenage pregnancy, potential lawyers, doctors, engineers and architectures fail to get an education. The saying goes, "Educate a woman and you, educate a nation".

(1)Societal support and unconditional love is called for when girls drop out of school.

(2)In addition, friends of girls who are unfortunate to fail pregnant at school ,are encouraged to offer the needed support

(3)The extended families are called upon to support the girl drop outs.

(4). School counselors are exhorted to be trustworthy and should not divulge information given to them in confidence otherwise learners lose trust in them.

(5).Neighbors are urged not to jeer and pass cruel comments about girl child drop outs.

(6) Verbal and physical abuse injures the girl child drop outs' self-esteem and must be avoided at all costs.

\section{REFERENCES}

Amedeker, M.A. (2011) Bsc, Thesis -Causes And Effects Of Female Drop Out Ad Financial Impact On Government Budget. Ayeduse Township - Department Of Statistics And Actuarial Science Kwame Nkrumah University Of Science And Technology - Kumasi : Ghana.

Best, J.W. and Khan, J (1995) Research in education, Needham Heights, M.A. Allyn and Bacon

Bond, T. (1990) Games for social and life schools. London. Stanley Thorns publishers

Brown, J.D.(2002) .Mass Media Influence on Sexuality. The Journal of Sex Research:42-45

Chapman , C., Laird,J., Ifill,.N. and KewalRamani,A. (2011) Trends in High School Drop Out and Completion Rates in the United States, National Centre for Education Statistics

Chiromo, A.S. (2006) Research Methods And Statistics In Education; A Student Guide: Harare. Zimbabwe.

Chitando, E.(2006) Acting in Hope: African Churches and HIV/AIDS. Volume two. Geneva; World, Council of Churches.

Davison, G.C. and Neale, J.M. (1990) Abnormal Psychology. New York: John Wiley and Sons

Dube, M.W. (2001) Other ways of reading the Bible: African women and the bible, Geneva; World Council of Churches.

Dube, M.W. (2003) Africa Praying : A handbook of HIV/AIDS - Sensitive Sermon Guidelines And Liturgy. Geneva;World Council of Churches

Gray, D.E. (2004) Doing Research In The Real World, London : Sage Publication

Gelfand,M.. (1979) Growing up in a Shona society : From birth to marriage. Gweru: Mambo Press 
Guitrrez, YK and King, J.C. (2003) Nutrition during teenage pregnancy, Ped iatr Ann 22 (2) :99-100. PMID 8493060.

Gwimbi ,P .and Dirwai ,C. ( 2003 ).Research Methods in Geography and Environmental Studies. Harare: Zimbabwe Open University

Jacobson, L.J. (2001) The Younger Siblings Of Teenage Mothers : A Follow Up Of Their Pregnancy Risk: Developmental Psychology 37 (2) 254-64.

Muchengetwa ,S.C. (2005).Research Methods and Environmental Studies STAT 102. Harare: Zimbabwe Open University

Odimegwu , C,. Mkwananzi, S. (2016) Factors Associated with Teen Pregnancy in Sub- Saharan Africa: A Multi-Country Cross- Sectional Study. African Journal of Reproductive Health 20 (3): 94-107

Ogori A. F . Ajeya S. and Yunasa A .R. The Cause And Effect Of Teenage Pregnancy: Case Of Kontagora Local Government Area In Niger State, Northern Part Of Nigeria . International Open Journal of Educational Research Vol. 1, No. 7, November 2013, PP: 01 - 15

Slavin, R.E. (2000) Educational Psychology : Theory and Practice , New York, Library of Congress Cataloguing in Publications Data

Tsoaledi D. and Thobejane K (2015) Factors Contributing to Teenage Pregnancy in South Africa: The Case of Matjileng Village. Journal of Sociology and Anthropology. 6(2): 273-277 (2

Traffers, P.E. (2003) Teenage Pregnancy, A Worldwide Problem, dscr Geneeskd (In Dutch and Flemish, 147 (47) 2320-5

Yin, R.K. (1994) Case Study Research Design And Methods: Applied Social Research Methods Series. Thousands Oaks: Sage

Sultana. A ( 2011) Patriachy and Women's Surbodination : A Theoretical Analysis The Arts Faculty Journal, July 2010- June 2011 